\title{
PEMANFAATAN MEDIA KOMUNIKASI WHATSAPP UNTUK MENGOPTIMALISASI KINERJA JURNALIS DITENGAH PANDEMI COVID-19.
}

I Ketut Manik Asta Jaya ${ }^{1}$

Universitas Hindu Negeri I Gusti Bagus Sugriwa Denpasar

Abstract

Keywords
This study aims to examine more deeply the benefits of Whatsapp communication media to optimize the performance of journalists in the midst of the covid 19 pandemic. Especially now that the whole world including Indonesia is still in the midst of the covid-19 pandemic, thus requiring all activities to be limited while still implementing health protocols. In the midst of this condition, technological advances with various features are a solution to keep carrying out various activities, especially the profession as a journalist. This study uses a quantitative approach because it uses research strategies such as survey activities that require statistical data. The results of this study indicate the high use of the Whatsapp application by respondents who are all journalists. In fact, one of the results of the questionnaire distributed through Google Forms shows that 100 percent of respondents choose the use of the Whatsapp application compared to applications such as Facebook, Twitter, Google Meet and other applications. These results show that the Whatsapp application supports the performance of journalists, especially in the midst of the covid 19 pandemic. In addition, the dominant respondents also choose the Whatsapp application to disseminate news links, compared to social media such as Facebook, Twitter and others. This result also causes many features in the Whatsapp application that support performance as a journalist. There are several features in the Whatsapp application: 1. Can send text messages, 2. Receive and send photos from live cameras or albums, 3. Send videos, 4. Exchange documents both in the form of files and others and various other features.

Utilization, Communication, Whatsapp, Journalist

${ }^{1}$ astajayaketut@uhnsugriwa.ac.id 


\section{PENDAHULUAN}

Pandemi yang disebabkan wabah corona virus desiase 2019 (Covid 19) telah mengganggu berbagai sektor kehidupan. Mulai dari sektor kesehatan, ekonomi, pendidikan dan sektor lainya telah terganggu karena pandemi ini. Tidak terkecuali sektor media komunikasi sebagai penyalur informasi, juga terganggu dengan adanya wabah corona ini. Terutama diawal munculnya pandemi di Indonesia pada 2020, banyak jurnalis yang kesulitan memperoleh informasi, terutama pengambilan gambar. Hal ini terjadi karena para kuli tinta pun harus mematuhi protokol kesehatan, belum lagi adanya ancaman tertular virus, dikarenakan harus meliput langsung ke lokasi warga yang terinveksi.

Ditengah kondisi ini tentu kalangan jurnalis tidak bisa berpangku tangan, terlebih kantor redaksi dari masing-masing media tetap menuntut adanya berita. Menyikapi hal ini para jurnalis telah memanfaatkan media teknologi, dengan berbagai fitur aplikasi hingga media sosial, yang bisa dimanfaatkan untuk memperoleh informasi. Berbagai fitur aplikasi dan media sosial ini juga difungsikan untuk menyelurkan informasi. (Anjani et al., 2018) mengatakan perkembangan teknologi telah banyak memberikan pengaruh dalam setiap aspek kehidupan manusia, salah satunya dalam hal komunikasi. Teknologi komunikasi yang semakin maju dan canggih, tentu berakibat pada informasi yang sangat berlimpah dan seakan tidak memiliki batas lagi. Untuk terwujudnya efektivitas dalam berkomunikasi diperlukan adanya media. Sementara itu, (Astajaya, 2020) mengatakan masyarakat di era revolusi industri 4.0 ini memiliki berbagai akses untuk berkomunikasi, salah satunya ialah memanfaatkan media sosial dengan berbagai fitur aplikasi. Hampir seluruh komponen masyarakat kini memiliki akun media sosial. Media sosial, bahkan telah memutus jarak kelas sosial, hingga memudahkan komunikasi lintas negara. Adapun aplikasi yang dapat dimanfaatkan seperti Facebook, Whatsapp, zoom, youtube, Instagram.

Berdasarkan penjabaran tersebut mengungkapkan bahwa perkembangan teknologi sudah banyak memberikan pengaruh dalam kehidupan masyarakat, terutama dalam bidang komunikasi. Terlebih di massa pandemi seperti sekarang, ada berbagai aplikasi yang bisa dimanfaatkan untuk mendukung jalannya berbagai profesi ditengah pandemi covid 19. Salah satu aplikasi yang paling banyak dimanfaatkan ialah aplikasi Whatsapp. Whatsapp merupakan aplikasi pesan lintas platform yang memiliki fungsi untuk mengirim dan menerima pesan dengan gratis tanpa dikenakan biaya SMS, hal ini dikarenakan paket data internet yang sama untuk email, browsing web, berlaku juga untuk penggunaan Whatsapp.

Dikutip dari (Untari, 2020) mengatakan Whatsapp awalnya didirikan oleh dua mantan karyawan yahoo, brian acton dan Jan Koum. Aplikasi ini kemudian diluncurkan pada Nopember 2009. Selang beberapa tahun kehadiran Whatsapp semakin dicintai pengguna, bahkan pada 2013 Whatsapp mengklaim 400 juta pengguna aktif. Selanjutnya pada 19 Februari 2014, Facebook, inc. mengakuisisi Whatsapp sebesar USD 19 Miliar. 18 Januari 2016, salah satu pendiri Whatsapp, Jan Koum mengumumkan bahwa mereka tidak akan membebankan biaya berlangganan kepada pengguna. Bahkan aplikasi tersebut tidak akan menampilkan iklan pihak ketiga 
mana pun dengan tetap update fitur-fitur baru.

Pengguna Whatsapp sebagai pesan instant terpopuler didunia telah mencapai 1 milliar pengguna aktif setiap harinya, ratarata 1,3 milliar pengguna pengguna aktif menggunakan whatssap tiap bulan, dari 55 milliar pesan, 4,5 milliar diantaranya berupa foto, sementara 1 milliar adalah video, mayoritas pesan berupa tulisan, sedangkan di Indonesia pengguna whatssapp mencapai angka 58\% (Anjani et al., 2018). Sementara itu (Sukrillah, 2017) dalam penelitianya menjabarkan peran Whatsapp mampu menjembatani informasi yang terputus maupun lamban dengan memaksimalkan group yang ada dan mengembangkan silaturahmi yang berbasis informasi kampus. Beberapa pengajar dan mahasiswa memanfaatkan Whatsapp sebagai bagian dari media yang mampu berinteraksi langsung terhadap perkuliahan. (Suryani, 2017) menunjukan bahwa bahwa penggunaan Whatsapp memang mempengaruhi kinerja karyawan sehingga penggunaan Whatsapp pada karyawan dapat meningkatkan kinerja karyawan. Untuk itu dengan data-data yang ada maka bisa pula Whatsapp digunakan sebagi salah satu fasilitas yang digunakan oleh karyawan untuk lebih kerja maksimal jika karyawan memanfaatkan Whatsapp dalam melakukan segala kegiatan dalam pekerjaan.

Berdasarkan kutipan diatas dapat diketahui bahwa aplikasi Whatsapp telah banyak membantu dalam menjembatani penyaluran informasi yang lebih efektif dan efisien. Sehingga tidak salah aplikasi ini banyak menjadi pilihan sebagai media komunikasi dalam berbagai sektor kehidupan, tidak hanya dunia pendidikan, kesehatan, pemerintahan, termasuk juga dunia jurnalistik yang justru membutuhkan mengiriman informasi secara cepat dan akurat. Dalam penelitian ini lebih fokus mengkaji pemanfaatan media komunikasi menggunakan aplikasi Whatsapp dalam mengoptimalkan kinerja jurnalis. Penelitian ini dilakukan untuk mengetahui lebih jelas pemanfaatan aplikasi Whatsapp sebagai media komunikasi, yang dapat mengoptimalkan kinerja profesi jurnalistik, terutama ditengah pandemik covid 19.

\section{METODE PENELITIAN}

Penelitian ini menggunakan pendekatan kuantitatif. Menurut (Amzir, 2008) pendekatan kuantitatif adalah suatu pendekatan penelitian yang secara primer menggunakan paradigma positivistik untuk mengembangkan ilmu pengetahuan dan menggunakan strategi penelitian seperti kegiatan survei yang memerlukan data statistik. Penelitian ini juga menggunakan metode analisis deskriptif dengan menyebarkan survei untuk menggali informasi dari para responden, yaitu wartawan aktif yang bertugas di media cetak, online dan televisi. Wartawan yang dipililh sebagai wubjek penelitian berjumlah 20 orang. Prosedur penelitiannya terdiri dari: 1) persiapan dan mengembangkan instrumen penelitian, 2) penyebaran dan pengumpulan angket, 3) melakukan kajian dan analisis data. Pengambilan data respon para wartawan terhadap pemanfaatan media whatsapp, dilakukan menggunakan Google Form, diperoleh dengan memberikan angket kepada responden. Penyebaran kuisioner dimulai pada tanggal 5 Februari sampai dengan 30 Maret 2021.

Metode pengumpulan data yang dilakukan dalam penelitian ini adalah angket. Jenis angket atau kuisioner yang digunakan pada penelitian ini adalah kuesioner campuran. Kuisioner ini 
merupakan perpaduan antara jenis kuesioner terbuka dan tertutup. Bisanya teknik ini dipergunakan selain mengetahui topik yang mendalam guna mendapatkan serangkaian data-data penelitian berupa angka.

\section{PEMBAHASAN}

\section{Hasil Penelitian}

Hasil penelitian menggunakan metode angket, yang dilakukan melalui link google formulir ini. Dalam link google form tersebut peneliti mencantumkan 15 pertanyaan, terkait aplikasi yang digunakan dalam aktifitas komunikasi sehari-hari, terutama dalam mendukung aktifitas profesi sebagai jurnalis. Dari 10 pertanyaan yang tercantum dalam google form, tiga diantaranya sebagai berikut; 1 . Aplikasi apa yang digunakan sebagai jurnalis untuk berkomunikasi dengan kantor media tempat bekerja, 2. Aplikasi apa yang digunakan sebagai jurnalis untuk berkomunikasi dengan sesama rekan jurnalis, 3. Aplikasi apa yang digunakan sebagai jurnalis untuk berkomunikasi dengan narasumber. Menjawab tiga pertanyaan ini, penulis mencantumkan beberapa pilihan ganda sebagai jawaban dalam google formulir, seperti Whatsapp Facebook, Twitter, Googlemeet, zoom dan aplikasi lainya. Selain pilihan tersebut, para pertanyaan berikutnya penulis juga mencantumkan sejumlah pilihan, yang sudah disesuaikan dengan substansi pertanyaan.

Ada 20 responden yang menjawab pertanyaan dari penulis, melalui link google formulir yang sudah dikirim. Hasilnya menunjukan penggunaan aplikasi Whatsapp yang tergolong tinggi. Hal ini dibuktikan dari jawaban para jurnalis yang dipilih sebagai responden. 100 persen jurnalis yang dipilih sebagai responden menjawab aplikasi Whatsapp sebagai media komunikasi dalam aktifitas sehari-hari. Hasil 100 persen ini menjawab tiga pertanyaan seperti yang dicantumkan diatas, yakni penggunaan aplikasi Whatsapp untuk berkomunikasi dengan kantor media tempat bekerja, berkomunikasi dengan sesama jurnalis hingga pemanfaatan aplikasi Whatsapp untuk berkomunikasi dengan narasumber. Hasil penelitian juga menunjukan, bahwa tidak ada responden yang menjawab pilihan Facebook, Twitter, Googlemeet, zoom dan aplikasi lainya.

\section{Aplikasi apa yang sering anda gunakan untuk berkoordinasi dengan narasumber? 20 jawaban}

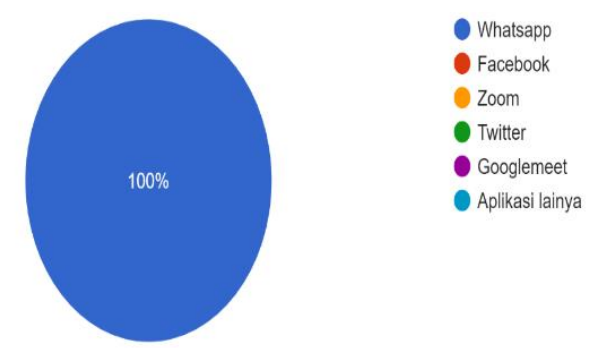

Gambar 1. Diagram Presentase Jumlah Responden Yang Memanfaatkan Whatsapp Sebagai Media Komunikasi Dengan Narasumber

Hasil penelitian melalui google Whatsapp menjadi aplikasi yang sering formulir ini juga menunjukan bahwa aplikasi digunakan oleh para responden. Hal ini 
dibuktikan dari 90 responden dalam google formulir, menyatakan setiap saat mengecek aplikasi Whatsapp. Hasil ini juga menunjukan tingginya penggunaan aplikasi Whatsapp yang setiap saat dipantau oleh kalangan jurnalis. Sementara 10 persen responden menyatakan pengecekan aplikasi whatspan dilakukan beberapa kali dalam satu jam.

Terkait aktifitas komunikasi melalui aplikasi whatsapp, dominan responden memilih komunikasi dengan narasumber berita. Bahkan responden yang memilih komunikasi dengan narasumber menggunakan aplikasi whatsapp, tercatat sebanyak 60 persen. 30 persen responden memilih komunikasi dengan sesama jurnalis. Sementara 10 persen jurnalis memilih komunikasi dengan keluarga.

Penelitian yang dilakukan lewat google form ini juga menunjukan, 55 persen responden menggunakan whatsapp mencari informasi untuk bahan berita. Responden juga mencantumkan pilihan menerima informasi secara langsung dari lapangan sebanyak 30 persen. Ada pula 10 persen responden mengaku mencari informasi bahan berita dari facebook, dan 5 persen responden mencari informasi sebagai bahan berita dari instagram. sementara itu tidak ada responden yang memilih mencari informasi lewat penggilan telepon/sms, dan tidak ada responden memilih mencari informasi dari twiiter atau aplikasi lainya.

Selain mencari informasi, dominan responden juga memilih aplikasi whatsaap, karena telah memberikan informasi sebagai bahan berita. Hasil ini dipilih oleh 70 persen responden. 20 persen responden memilih menerima informasi dari facebook, dan 10 persen responden memilih melihat langsung informasi di lapangan. Sementara itu tidak ada responden yang memilih menerima informasi lewat penggilan telepon/sms, dan tidak ada responden memilih menerima informasi dari twiiter atau aplikasi lainya.

Terkait sumber berita yang diterima melalui aplikasi whatsapp, 45 persen responden mengungkapkan menerima informasi terkait peristiwa dan bencana alam. Sementara 35 persen responden memilih menerima informasi hukum pidana melalui whatsapp. Sementara 15 persen responden menerima informasi terkait keluhan masyarakat. Sementara responden yang memilih menerima informasi tentang kebijakan pemerintah dari pesan whatsaap sebanyak 5 persen.

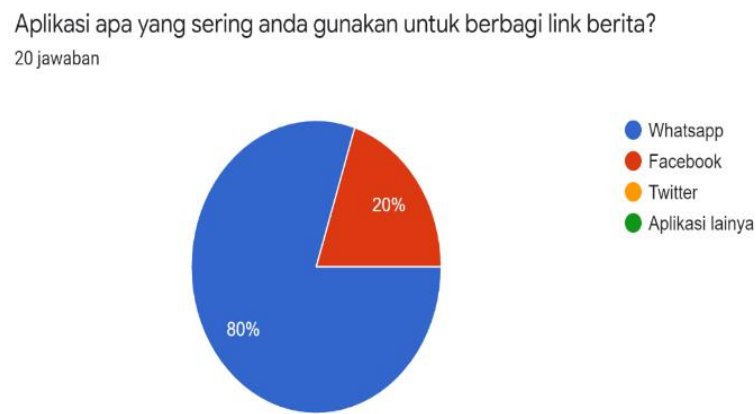

Gambar 2. Diagram Presentase Kegunaan Aplikasi Whatsapp Yang Dimanfaatkan Sebagai Media Komunikasi Untuk Menyebar Link Berita Oleh Para Responden.

Hasil penelitian ini juga menunjukan tingginya pengguanaan aplikasi Whatsapp, yang digunakan para jurnalis dalam menyebarkan link berita. Hal ini dibuktikan 
dari 80 persen responden dalam pilihan ganda menjawab aplikasi Whatsapp, yang dimanfaatkan untuk menyebarkan link berita yang sudah diproduksi oleh masingmasing media. Sementara itu ada 20 persen responden menjawab aplikasi Facebook, yang digunakan oleh para jurnalis untuk menyebarkan link berita. Sementar pilihan seperti Twitter, Googlemeet, zoom dan aplikasi lainya tidak dimanfaatkan oleh para jurnalis dalam menyebarkan link berita yang sudah diproduksi oleh masing-masing media.

Melalui penelitian ini, para responden juga mencantumkan pilihan bahwa Whatsapp sebagai aplikasi paling mendukung dalam menjalankan profesi sebagai jurnalis. Hal ini dibuktikan dari 100 persen koresponden yang menjawab ya dalam pilihan ganda pada google formulir. Hasil ini juga menunjukan bahwa aplikasi Whatsapp memberi manfaat besar dalam mendukung kinerja untuk profesi jurnalis, terlebih dimasa pandemi covid, aplikasi Whatsapp telah memberikan berbagai manfaat sehingga menjadi pilihan para responden. Tingginya pilihan tersebut juga dikaitkan dengan mudahnya mamanfaatkan aplikasi Whatsapp, yang sudah bisa digunakan hanya dari handphone. Bahkan dalam google formulir, 100 persen responden mengaku menggunakan Whatsapp melalui handphone. Sementara pilihan lain yang dicantumkan peneliti dalam google formulir seperti laptop, komputer dan perangkat lainnya tidak menjadi pilihan para responden.

Whataspp juga menjadi aplikasi yang sudah sejak lama membantu memudahkan kinerja responden yang seluruhnya berprofesi sebagai jurnalis ini. Bahkan dominan responden sudah menggunakan aplikasi ini lebih dari lima tahun, tercatat 65 persen responden memilih penggunaan Whatsapp sejak lebih dari lima tahun. Selanjutnya ada 15 persen responden mengaku sudah memanfaatkan aplikasi Whatsapp sejak lima tahun lalu dan 15 persen responden juga menyebut sudah memanfaatkan aplikasi Whatsapp sejak empat tahun lalu. Sementara itu ada 5 persen responden mengaku baru menggunakan aplikasi Whatsapp sejak dua tahun lalu.

\title{
Sejak kapan anda menggunakan aplikasi WhatsApp 20 jawaban
}

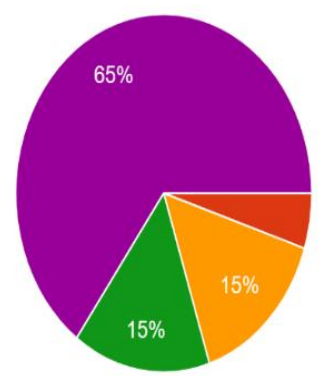

\author{
Setahun lalu \\ Dua tahun lalu \\ Empat Tahun lalu \\ Lima tahun lalu \\ lebih dari lima tahun lalu
}

Gambar 3. Diagram Presentase Jumlah Responden Mengukur Konsistensi Waktu Penggunaan Whatsapp Sebagai Media Komunikasi

\footnotetext{
Hasil dalam diagram tersebut menunjukan bahwa Whatsapp sebagai

aplikasi yang paling populer digunakan oleh para jurnalis, bahkan rata-rata responden 
sudah memanfaatkan aplikasi ini sejak lebih dari lima tahun. Hal ini mengingat aplikasi ini sudah diluncurkan sejak 2009. Hingga kini Whatsapp masih menjadi pilihan para responden yang berprofesi sebagai jurnalis, untuk membantu mengoptimalkan dalam menjalankan tugas. Terutama untuk berkomunikasi dengan rekan sejawat hingga narasumber, terkait berbagi informasi terbaru yang akan dijadikan materi berita.

\section{Pembahasan Hasil Penelitian}

Hasil penelitian terhadap para responden yang seluruhnya merupakan kalangan jurnalis ini, menunjukan tingginya pemanfaatan aplikasi Whatsapp dalam mendukung aktifitas sehari-hari menjalankan profesi sebagai jurnalis. Bahkan hasil penelitian menunjukan adanya pemanfaatan aplikasi Whatsapp sampai 100 persen, sementara aplikasi lain seperti Facebook, tweeter, googlemett, zoom dan aplikasi lainya itu tidak ada yang dipilih responden. Bila dicermati secara seksama, tentu hal ini cukup beralasan karena Whatsapp merupakan media sosial berbentuk aplikasi chating, yang dengan mudah dapat digunakan melalui smartphone. Aplikasi ini juga memiliki berbagai fitur yang mudah dipahami dan mendukung aktifitas kerja khususnya sebagai jurnalis.

(Anjani et al., 2018) mengatakan penggunaan suatu media harus diringi dengan pengetahuan atau tentang cara menggunakan. Keterampilan dalam menggunakan suatu produk merupakan proses dari ketidaktahuan menjadi tahu, tidak dikenal menjadi kenal, tidak paham menjadi paham. Karena tidak semua orang dapat mengetahui, mengenal dan memahami suatu produk. menurut ada beberapa faktor yang dapat mempengaruhi kita dalam menggunakan suatu produk dalam hal ini adalah Whatsapp. Faktorfaktor tersebut diantaranya; Pengetahuan tentang karakteristik bagaimana cara mendonwoald dan menggunakan nya serta fitur-fitur yang ada pada Whatsapp. (2) Manfaat yang didapatkan dari Whatsapp, keunggulan dan kemudahan apa saja yang diperoleh ketika menggunkan Whatsapp. (3) Penggunaan pada segi waktu, yaitu berapa lama Whatsapp bisa digunakan jika tersambung dengan koneksi internet, tujuan penggunaan Whatsapp, biaya penggunaan yang dikeluarkan jika menggunakan Whatsapp, kemudahan penggunaan dibanding dengan aplikasi lain.

Pemenuhan tiga faktor tersebut tentu menjadi alasan, didaptnya hasil 100 persen responden memilih Whatsapp sebagai media komunikasi, dibandingkan keberadaan aplikasi lain. Hasil tersebut juga menunjukan bahwa tiga faktor tersebut diatas sudah dipahami dengan baik oleh para responden. Karena pemahaman itu pula, sebagai jurnalis lebih memilih Whatsapp untuk dimanfaatkan dalam berkomunikasi, baik itu dengan teman sejawat, kantor redaksi hingga dengan narasumber.

(Rusni, 2017) mengatakan Whatsapp juga memiliki fungsi sebagai pesan instant yang dapat mengirim dan menerima pesan, tanpa dikenakan biaya pulsa seperti SMS dan telepon seluler. Hal ini dikarena Whatsapp menggunakan paket data internet yang sama dengan aplikasi lainnya. Jaringan data internet yang diperlukan untuk menjalankan aplikasi Whatsapp ialah koneksi $3 G$ atau WiFi. Fiturfiur yang dapat digunakan pada Whatsapp yaitu, melakukan personal /group chat (online), mengirim dokumen, mengirim foto, video, audio, lokasi. 
Tingginya pemanfaataan aplikasi Whatsapp oleh responden, juga disebabkan beberapa fitur-fitur yang memang mendukung profesi jurnalis. Seperti yang diungkapkan (Rusni, 2017) ada sejumlah fitur yang dapat memudahkan para pengguna Whatsapp, diantaranya; 1. Mengirim pesan teks, 2. Menerima dan mengirim foto dari kamera langsung maupun album, 3. Mengirim video, 4. Bertukar dokumen baik dokumen berupa file maupun yang lainnya, 5. Melakukan panggilan telepon dan panggilan video ataupun megirim rekaman suara secara langsung, 6. Berbagi lokasi memanfaatkan GPS, 7. Mengirimkan kartu kontak, 8. Bertukar emotikon maupun stiker melaui personal chat maupun group chat, 9. Dapat mengganti foto profil, tulisan status, mencadangkan pesan, menggati nomer dan menjaga keamanan akun dan mengatur privasi dalam menggunakan Whatsapp pada fitur pengaturan.

(Rusni, 2017) juga menyebutkan beberapa kelebihan yang dimiliki Whatsapp dibandingkan berbagai aplikasi lain yang kini juga banyak tersedia di playstore. Adapun kelebihan aplikasi Whatsapp diantaranya: 1 . Tidak memerlukan uang untuk memasang aplikasi Whatsapp ditelpon pintar dan biayanya percuma. 2. Bisa menghantar message, gambar, video, audio dan pesan suara dengan mudah. 3. Dapat melakukan obrolan dengan orang lain dengan kuota lebih dari 70 orang dalam satu chat group. 4. Penggunaan data yang kecil berbanding aplikasi-aplikasi lain.

Berdasarkan penjabaran tersebut diketahui bahwa berbagai fitur-fitur dalam aplikasi Whatsapp memang bermanfaat mendukung kinerja sebagai jurnalis. Mulai dari mengirim pesan yang jumlahnya banyak, sehingga membantu untuk pengiriman narasi berita yang panjang. Termasuk juga dalam mengirim foto secara langsung dari kamera, fitur ini sangat membantu untuk memenuhi kebutuhan akan kecepatan dalam update informasi faktual yang ditunjang dengan bukti foto. Dalam mempercepat pengiriman foto, seorang jurnalis yang bertugas di lapangan, juga tidak perlu melakukan compres terlebih dahulu, sebab Whatsapp akan melakukan compres foto secara otomatis, sehingga file foto dapat menjadi lebih ringan dan terkirim lebih cepat. Hal ini juga berlaku untuk pengiriman video, rekaman suara hingga dokumen-dokumen penting, yang bisa dikirim dengan lebih cepat melalui aplikasi Whatsapp. Mempertimbangkan analisis tersebut, maka tidak salah bila seluruh responden yang merupakan jurnalis bertugas aktif melakukan peliputan seritap hari di lapangan, telah mencantumkan pilihan pada Whatsapp sebagai aplikasi paling mendukung dalam menjalankan profesi sebagai jurnalis. Hal ini dibuktikan dari 100 persen responden yang menjawab ya dalam pilihan ganda pada google formulir.

(Anjani et al., 2018) dalam penelitiannya menjabarkan penggunaan media komunikasi Whatsapp dalam lingkungan kerja membuat responden mengetahui bahwa dengan penggunaan Whatsapp berdampak pada efktivitas kinerja sehingga berpengaruh pada hasil kerja. Artinya ada hubungan antara penggunaan media komunikasi Whatsapp terhadap efektivitas kinerja. Sementara itu, (Changara, 2016) mendefinisikan suatu proses komunikasi tidak akan berlangsung tanpa didukung oleh unsur-unsur pengirim (source), pesan (message), saluran/media (channel), penerima (receiver), dan akibat/pengaruh (effect). Artinya media komunikasi memiliki peranan penting dalam 
proses komunikasi. Sama halnya dengan penelitian sebelumnya yang dilakukan (Suryani, 2017) pada dasarnya Whatsapp merupakan aplikasi media sosial berupa Percakapan (chat) yang secara langsung (real time) dapat mengirim pesan dengan mudah. Dibekali dengan fitur-fitur yang mumpuni seperti Whatsapp group yang memudahkan karyawan untuk membuat group yang memang digunakan sebagai media untuk sesama karyawan, bisa saling berdiskusi mengenai pekerjaannya. Selain itu terdapat fitur Whatsapp call yang membuat karyawan lebih dimudahkan dan diuntungkan jika menggunakan aplikasi Whatsapp dalam pekerjaannya. Kemudahan yang ditawarkan.

Berdasarkan penjabaran tersebut, maka tidak salah para responden yang merupakan pengguna smartphone seluruhnya memanfaatkan aplikasi Whatsapp, hal ini terjadi karena responden yang berprofesi sebagai jurnalis ini dipermudah dengan berbagai fitur dalam aplikasi tersebut. Tidak hanya sering digunakan, para responden juga konsisten menggunakan aplikasi ini dalam waktu yang lama. Hasil ini disebabkan karena fitur yang ada pada aplikasi Whatsapp mudah untuk dipahami. Terutama untuk menjalankan profesi sebagai jurnalis, berbagai fitur tersebut memberikan dukungan untuk memudahkan pengiriman data, hingga foto. Fitur yang ada pada aplikasi ini juga memudahkan dalam berbagi infromasi berupa link.

Selain berbagai fitur yang menjadi kelebihan dari penggunaan Whatsapp, ada juga beberapa kelemahan dalam penggunaan aplikasi ini. Seperti susahnya komunikasi akibat gangguan signal bila pengguna berada di lokasi dengan kualitas signal berbeda. Kondisi ini sering mengganggu saat peliputan lapangan, terutama ketika jurnalis melakukan peliputan di kawasan dalam yang jauh dari pemancar signal. (Yensy, 2020) dalam penelitian tentang penggunaan Whatsapp group mengungkapkan berbagai kelemahan dari penggunaan aplikasi Whatsapp, 1) Mahasiswa berada di lokasi yang berbeda dengan kekuatan sinyal yang berbeda pula, sehingga tidak sedikit yang mengeluhkan kesulitan sinyal untuk dapat bergabung selama proses pembelajaran berlangsung. Hal ini mengakibatkan mahasiswa ketinggalan materi karena tidak tepat waktu mengikuti kegiatan pembelajaran. 2) Banyaknya chat di WA Group membuat memori $\mathrm{Hp}$ penuh sehingga koneksi internet menjadi lambat. 3) Jika chat sudah banyak, maka untuk cukup sulit karena harus scrool lagi $\mathrm{Hp}$ ke atas agar bisa mengikuti jalannya diskusi selama pembelajaran berlangsung.

Sementara itu (Artaviamita, 2019) dalam penelitiannya juga mengungkapkan kekurangan aplikasi Whatsapp. Sasaran penerima dakwah melalui aplikasi Whatsapp terbatas, pesan video atau status dakwah hanya bisa di lihat oleh kontak saja, orang lain yang tidak menjadi kontak tidak bisa pesan dakwah terebut jadi penerima pesan dakwah hanya orang orang tertentu saja. Pesan yang terbatas menjadikan penerima pesan dakwah sedikit dan tidak menyeluruh seperti media sosial lainnya, jika instagram, Facebook, blog dan aplikasi lainnya dapat dilihat dengan mudah oleh semua orang dengan mengetikan kata kuci nya di pencarian, media Whatsapp tidak bisa seperti itu. Jadi, jika ingin mendapatkan pesan dakwah melalui status dan pesan teks semua pihak harus menyimpan nomer satu sama lain. Tapi jika melalui grup pesan dakwah dapat langsung masuk namun kita terlebih dahulu masuk ke grub tersebut. 
Terbatasnya penerima pesan dari aplikasi Whatsapp, juga dirasakan para jurnalis dalam menyebarkan link berita. Namun para responden masih tetap dominan menggunakan aplikasi Whatsapp untuk menyebarkan link berita yang sudah termuat di media online.

Kelemahan lain aplikasi ini ialah menurunnya kualitas file yang dikirim, hal ini sebagai akibat dari resize file yang dilakukan secara otomatis oleh aplikasi Whatsapp. Turunnya size file seperti file foto atau video, akan menurunkan kualitas tampilan file foto atau video itu sendiri. Seperti file foto dengan size kecil, tidak akan layak bila pajang dengan ukuran besar pada pada media cetak, hal ini terjadi karena foto tersebut akan terlihat pecah bila dipaksa pada layout dengan ukuran besar

\section{PENUTUP}

\section{Simpulan}

Berdasarkan uraian tersebut maka dapat diambil beberapa kesimpulan sebagai berikut;

1. Hasil penelitian berupa kuisioner yang dikirim lewat google formulir ini menunjukkan tingginya pililhan responden terhadap penggunaan aplikasi Whatsapp. Bahkan 100 persen responden yang berprofesi sebagai jurnalis ini memilih untuk memanfaatkan aplikasi Whatsapp, dibandingkan aplikasi lain seperti Facebook, twetter, zoom, google meet dan aplikasi lainya. Penggunaan tersebut meliputi untuk berkoordinasi dengan teman sejawat, kantor redaksi, hingga berkoordinasi dengan narasumber. Penggunaan aplikasi Whatsapp juga memberi kontribusi besar mendukung kinerja sebagai jurnalis, terbukti dari 70 persen responden memilih menerima informasi bahan berita melalui aplikasi whatsapp. Tidak hanya itu 80 persen responden juga memiliki aplikasi Whatsapp untuk menyebarkan link berita yang sudah diterbitkan oleh kantor redaksi. Sementara 20 persen responden memilih menyebarkan link berita lewat Facebook. Sementara twetter, zoom, google meet dan aplikasi lainya itu tidak dipilih oleh responden. Hasil penelitian ini juga menunjukan bahwa Whatsapp menjadi aplikasi yang paling sering digunakan oleh responden yang seluruhnya merupakan jurnalis ini. Hal ini dibuktikan berdasarkan hasil kuisioner dimana 90 persen responden menjawab setiap saat melakukan pengecekan pada aplikasi Whatsapp. Hasil ini juga menunjukan tingginya penggunaan aplikasi Whatsapp yang setiap saat dipantau oleh kalangan jurnalis. Terutama dalam hal ini terkait cara kerja jurnalis, meliputi mencari informasi, hingga menyebarkan informasi. Sementara 10 persen responden menyatakan pengecekan aplikasi whatspan dilakukan beberapa kali dalam satu jam.

2. Tingginya pemanfaatan aplikasi Whatsapp oleh responden tidak terlepas dari berbagai fitur yang ada dalam aplikasi tersebut, yang memang mendukung kinerja sebagai jurnalis. Mulai dari mengirim pesan yang jumlahnya banyak, sehingga membantu untuk pengiriman narasi berita yang panjang. Termasuk juga dalam mengirim foto secara langsung dari kamera, fitur ini sangat membantu untuk memenuhi kebutuhan akan kecepatan dalam update informasi faktual yang ditunjang dengan bukti foto. Dalam mempercepat pengiriman foto, seorang jurnalis yang 
bertugas di lapangan, juga tidak perlu melakukan compres terlebih dahulu, sebab Whatsapp akan melakukan compres foto secara otomatis, sehingga file foto dapat menjadi lebih ringan dan terkirim lebih cepat. Hal ini juga berlaku untuk pengiriman video, rekaman suara hingga dokumen-dokumen penting, yang bisa dikirim dengan lebih cepat melalui aplikasi Whatsapp.

3. Ada beberapa kelemahan aplikasi ini, mulai dari susahnya komunikasi akibat gangguan signal bila pengguna berada di lokasi dengan kualitas signal berbeda. Kelemahan lainya ialah terbatas penerima pesan status, yang hanya bisa dilihat oleh kontak tersimpan saja, orang lain yang tidak menjadi kontak tidak bisa mengetahui pesan, jadi penerima pesan hanya orang orang tertentu saja. Pesan yang terbatas menjadikan penerima pesan sedikit dan tidak menyeluruh seperti media sosial lainnya. Selain itu juga terjadi penurunan kualitas file yang dikirim melalui aplikasi Whatsapp. Hal ini sebagai akibat dari resize file yang dilakukan secara otomatis oleh aplikasi Whatsapp.

\section{DAFTAR PUSTAKA}

Amzir. (2008). Metodelogi Penelitian

Pendidikan Kuantitatif \& Kualitatif (Korelasional, Eksperimen, Ex Post Facto, Etnografi, Grounded Theory, Action Research. Rajagrafindo Persada.

Anjani, A., Ratnamulyani, I. A., \&

Kusumadinata, A. A. (2018). Penggunaan Media Komunikasi Whatsapp Terhadap Efektivitas Kinerja Karyawan. Jurnal Komunikatio, 4(1), 41-50.
Https://Doi.Org/10.30997/Jk.V4i1.121

1

Artaviamita, B. T. (2019). Fungsi

Komunikasi Whatsapp Dalam

Merepresentasikan Pesan Dakwah

Pada Mahasiswa Kpi Uin Raden Intan

Lampung. Universitas Islam Negeri

Raden Intan Lampung.

Astajaya, I. K. M. (2020). Etika Komunikasi Di Media Sosial. Widya Duta, 15, 81-95.

Changara, H. (2016). Pengantar IImu Komunikasi. Rajagrafindo Persada.

Rusni, A. (2017). Penggunaan Media Online

Whatsapp Dalam Aktivitas Komunitas One Day One Juz (Odoj) Dalam Meningkatkan Minat Tilawah Odojer Di Kota Pekanbaru.

Sukrillah, A. (2017). Pemanfaatan Media

Sosial Melalui Whatsapp Group Fei Sebagai Sarana Komunikasi. Jurnal Komunikatio, 3, 95-104. Https://Doi.Org/10.24036/Ld.V2i2.35 25

Suryani, N. (2017). Analisa Pengaruh Aplikasi Whatsapp Terhadap Kinerja Karyawan Pada Pt Tunas Kreasi Mandiri. Evolusi: Jurnal Sains Dan Manajemen, 5, 2.

Untari, P. H. (2020). Sejarah Whatsapp

Aplikasi Chat Paling Populer Saat Ini. Https://Techno.Okezone.Com/Read/2 020/01/18/207/2154693/Sejarah-

Whatsapp-Aplikasi-Chat-PalingPopuler-Saat-Ini

Yensy, N. A. (2020). Efektifitas Pembelajaran Statistika Matematika Melalui Media Whatsapp Group Ditinjau Dari Hasil Belajar Mahasiswa (Masa Pandemik Covid 19). Jurnal Pendidikan Matematika Raflesia, 05(02), 65-74. Https://Ejournal.Unib.Ac.Id/Index.Php $/ \mathrm{Jpmr}$ 